\title{
Effect of Calcium Chloride Treatments on Quality Characteristics of Blackberry, Raspberry and Strawberry Fruits After Cold Storage
}

\author{
Tamar Turmanidze ${ }^{1 *}$, Levan Gulua ${ }^{1}$, Merab Jgenti $^{1}$, Louise Wicker ${ }^{2,3}$
}

${ }^{I}$ Department of Food Technology, Agricultural University of Georgia, Kakha Bendukidze campus, Tbilisi, Georgia

${ }^{2}$ Department of Food Science and Technology, University of Georgia, Athens, GA, USA

${ }^{3}$ Department of Home Economics Education, College of Education, Korea University, Anam-Dong, Seongbuk-Gu, Seoul 136-701, Republic of Korea A R T I C LE IN F O
Article history:

Accepted 16 November 2016

Available online, ISSN: 2148-127X

Keywords:

Antioxidant

Berry fruits

Calcium chloride

Quality

Cold Storage

${ }^{*}$ Corresponding Author:

E-mail: tturm2010@agruni.edu.ge
Received 13 July 2016

\begin{abstract}
A B S T R A C T
Post-harvested blackberry, raspberry and strawberry fruits were immediately treated with
$1 \%$ and $2 \%$ calcium chloride by immersion at $20 \pm 1{ }^{\circ} \mathrm{C}$ for 2.5 min and kept for 8 days at
$0 \pm 0.5^{\circ} \mathrm{C}$ and relative humidity $(\mathrm{RH}) 90 \pm 5 \%$. The application of calcium did not
significantly effect on total titratable acidity, pH and total soluble solids. Maximum
weight lost was observed for untreated berries and minimum lost was observed for fruits
treated with $2 \%$ calcium chloride. After storage, ascorbic acid content was significantly
higher in samples of blackberry, raspberry and strawberry fruits subjected to $2 \%$ calcium
chloride dip. Treatment of blackberry, raspberry and strawberry fruits with calcium
chloride had a positive effect on retention of total polyphenols content during the storage
period. Depletion of antioxidant capacity of untreated fresh blackberry fruits during 8
days cold storage was $25 \%$; raspberries and strawberries - 34 and $26 \%$ respectively.
Whereas depletion of antioxidant activity in the $2 \%$ calcium chloride treated samples of
these fruits was 8,22 and $11 \%$ respectively. In case of storage of untreated blackberry
fruits content of cyanidin-3-O-monoglucoside decreased by 6.33 mg per $100 \mathrm{~g}$ of fruit.
While, in fruit samples treated with 1 and $2 \%$ calcium chloride content of cyanidin-3-O-
monoglucoside decreased by 32.06 and $11.35 \mathrm{mg}$ per $100 \mathrm{~g}$ of fruit, respectively. Content
of pelargonidin $3-\mathrm{O}-$ monoglucoside increased by 2.29 mg per $100 \mathrm{~g}$ of the untreated
blackberry fruits and by 26.87 and $8.45 \mathrm{mg}$ per $100 \mathrm{~g}$ of fruits treated with 1 and $2 \%$
calcium chloride respectively. Change of content of cyanidin $3-\mathrm{O}-(6-\mathrm{p}-$ coumaroyl -
glucoside) in blackberry fruits was not statistically significant.
Post-harvested blackberry, raspberry and strawberry fruits were immediately treated with $1 \%$ and $2 \%$ calcium chloride by immersion at $20 \pm 1{ }^{\circ} \mathrm{C}$ for 2.5 min and kept for 8 days at $0 \pm 0.5^{\circ} \mathrm{C}$ and relative humidity (RH) $90 \pm 5 \%$. The application of calcium did not significantly effect on total titratable acidity, $\mathrm{pH}$ and total soluble solids. Maximum weight lost was observed for untreated berries and minimum lost was observed for fruits treated with $2 \%$ calcium chloride. After storage, ascorbic acid content was significantly chloride dip. Treatment of blackberry, raspberry and strawberry fruits with calcium chloride had a positive effect on retention of total polyphenols content during the storage period. Depletion of antioxidant capacity of untreated fresh blackberry fruits during 8 these fruits was 8,22 and $11 \%$ respectively. In case of storage of untreated blackberry fruits content of cyanidin-3-O-monoglucoside decreased by $6.33 \mathrm{mg}$ per $100 \mathrm{~g}$ of fruit. While, in fruit samples treated with 1 and $2 \%$ calcium chloride content of cyanidin-3-Omonoglucoside decreased by 32.06 and $11.35 \mathrm{mg}$ per $100 \mathrm{~g}$ of fruit, respectively. Content of pelargonidin 3-O- monoglucoside increased by $2.29 \mathrm{mg}$ per $100 \mathrm{~g}$ of the untreated calcium chloride respectively. Change of content of cyanidin 3-O- (6-p - coumaroyl glucoside) in blackberry fruits was not statistically significant.
\end{abstract}

\section{Introduction}

Blackberry (Rubus fruticosus, cv. Chester), Raspberry (Rubus idaeus L. cv. Killarney) and Strawberry (Fragaria $\mathrm{x}$ ananassa. cv. Red Dream) fruits belongs to the Rubus genus in the Rosacea family. They are widely grown in Georgia and its consumption annually increases throughout the world. Berries are excellent sources of phytochemicals that are believed to have significant biological activity. Berry containing elevated levels of bioactive compounds (Skrovankova et al., 2015; Halvorsen et al., 2002; De Souza et al., 2014; Slatnar et al., 2012; Namiesnik et al., 2014; Diaconeasa et al., 2015), are attracting considerable attention due to their potential to lower the risk of chronic diseases and their associated huge healthcare costs (Beattie et al., 2005; Karlund et al., 2014; Pantelidis et al., 2007). Phenolics may contribute to this protective effect. Berries are very rich in health-promoting phytochemicals (Fortalezas et al., 2010). Many of these phytochemicals have antioxidant activity and may help protect cells against the oxidative damage caused by free radicals. (Wada et al., 2002; Prior et al., 2003; Ichiyanagi et al., 2004; Zheng et al., 2003; Panico et al., 2009). Berry can be used in the development of functional foods with the objective of enhancing health conditions (Potter et al., 2007). Different berries and berry phenolics possess considerable antimicrobial effects against, e.g. Salmonella and Staphylococcus (Puupponen-Pimia et al., 2005; Burdulis

However, berries are also highly perishable fruits due to their soft texture, high softening rate and high sensitivity to fungal attack. Quality declines rapidly after harvest, which must be done at full maturity, and storage life may be less than a week (Wills et al., 1998). This problem may be overcome with calcium chloride application (Astuti et al., 2013). The involvement of $\mathrm{Ca}$ in the regulation of fruit ripening is well established (Ferguson, 1984; Aghdam et al., 2012; Poovaiah, 1986). Calcium contributes in improving the rigidity of cell walls; retard tissue softening also reduces the accessibility of cell wall degrading enzymes to their substrates (Vicente et al., 2009). Moreover, calcium is considered to be an important mineral element that regulates fruit quality, specifically, maintenance of fruit firmness (Lurie et al., 2009, Machado et al., 2008). Effect of calcium et al., 2009). 
treatment on quality of fruits, has been investigated intensively (Garsia et al., 2001), but there is a lack of information about effect of calcium treatment on berry fruits. The objective of the present study was to investigate the effect of calcium treatment of blackberry, raspberry and strawberry fruits on the retaining ascorbic acid, anthocyanins, total polyphenols as well as other general quality parameters during storage period.

\section{Material and Methods}

\section{Chemicals}

Ascorbic acid and Potassium dihydrogen phosphate were purchased from Sigma - Aldrich (Steinheim, Germany), TPTZ - 2-4 - 6 - Tris (2 - pyridyl) - s triazine (Sigma - Aldrich, Switzerland), Folin - ciocalteu Reagent (Appli Chem, Germany), hydrochloric acid, formic acid and phosphoric acid were provided by Merck (Darm-stadt, Germany), Sodium carbonate was purchased from Chem Cruz (Chem Cruz Biochemicals, USA), Ethyl acetate and methanol (Sigma - Aldrich Steinheim, Germany) were HPLC grade. All other reagents were commercially available at the local market and were of analytical grades.

\section{Sample Collection}

Berry fruits were harvested in the middle summer in eastern part of Georgia. After harvesting average samples of fruits were treated with $0 \%, 1 \%$ or $2 \%$ calcium chloride solution at $20 \pm 1^{\circ} \mathrm{C}$ temperature with exposure time of $2.5 \mathrm{~min}$. The treated samples were stored for 8 days in refrigerator at $0 \pm 0.5^{\circ} \mathrm{C}$ and $90 \pm 5 \% \mathrm{RH}$.

\section{Sample Preparation}

Preparation of sample for ascorbic acid determination by HPLC (Varian - Prostar - 500, USA, detector - UV varian Prostar, Australia, column - 250 mm x $4.6 \mathrm{~mm}$, dp $=5 \mu \mathrm{m}$, Symmetry, Waters, Ireland) method was done according to Koyuncu et al. (2010). Briefly, sample (10 g) was extracted in $10 \mathrm{~mL}$ water adjusted to $\mathrm{pH} 1.5$ with 10 $\mathrm{mL}$ phosphoric acid-water $(2 \%, \mathrm{v} / \mathrm{v})$. The extracts were filtered through filter paper $45 \mu \mathrm{m}$ (Whatman, UK). Then, $1.5 \mathrm{~mL}$ buffer (0.01 $\left.\mathrm{M} \mathrm{KH}_{2} \mathrm{PO}_{4}, \mathrm{pH} 8.0\right)$ was added to 1.5 $\mathrm{mL}$ sample extract, $1 \mathrm{~mL}$ (vitamin - C) of preferred mixtures were loaded on to C 18 cartridges (Agilent, Bond Elut, USA). After loading, $3.0 \mathrm{~mL}$ water adjusted to pH 1.5 with $2.0 \mathrm{~mL}$ phosphoric acid-water $(2 \%, \mathrm{v} / \mathrm{v})$ were passed through the cartridges.

Samples for antioxidant analysis were prepared according to Rodriguez - Saona et al. (2001). About 40 g of berries were cryogenically milled in liquid nitrogen. Chilled test tubes were filled with milled fruit powder and weighed ( $5 \mathrm{~g})$, and then the powder was extracted with acetone $(200 \mathrm{~mL})$.The acetone was removed under vacuum in a rotary evaporator at $<30^{\circ} \mathrm{C}$ and then $250 \mathrm{~mL}$, $70 \%$ methanol was added to the powder. Total methanol extract was examined for antioxidant activity. Samples for anthocyanin analyses by High performance liquid chromatography, HPLC (Varian - Prostar - 500, USA, detector - UV varian Prostar, Australia, column - S 250 x
4.6, Agilent, Microsorb - 100 - 5, The Netherlands) were prepared according to Prior et al. (2012). Berries (40 g) were homogenized in methanol/water/formic acid in a ratio of 60: $37: 3(\mathrm{v} / \mathrm{v} / \mathrm{v})$, kept overnight $(14 \mathrm{~h})$ at $3-5^{\circ} \mathrm{C}$ and later filtered by filter $45 \mu \mathrm{m}$ (Whatman, UK) through a Buchner funnel under vacuum. The filtrates were centrifuged $\left(4000 \mathrm{X} \mathrm{g}, 15 \mathrm{~min}, 21^{\circ} \mathrm{C}\right)$ The supernatant was concentrated under vacuum in a rotary evaporator at < $30^{\circ} \mathrm{C}$ to total evaporation of the methanol. An aliquot (2.0 $\mathrm{mL}$ ) of the aqueous phase was carefully deposited onto a C - 18 cartridge (Agilent, Bond Elut, USA). sugars and more polar substances were removed by passing $2.0 \mathrm{~mL}$ of ultrapure water through the cartridge. polyphenols were removed by passing $2.0 \mathrm{~mL}$ of ethyl acetate and finally anthocyanin pigments were eluted with $10 \mathrm{~mL}$ of methanol. $10 \mathrm{~mL}$ deionized (DI) water was added to the methanol extract and then the methanol was removed under vacuum in a rotary evaporator at $<30^{\circ} \mathrm{C}$.

\section{Measures and Covariates}

Titratable acidity: Titratable acidity (TA) was determined by titration with $0.1 \mathrm{~N} \mathrm{NaOH}$ to a pink color using $1 \%$ phenolphthalein as indicator and expressed as $\mathrm{g}$ $100 \mathrm{~g}^{-1}$ citric acid, Morris et al. (1985).

Total Soluble Solids: Total Soluble Solids (TSS) was measured by digital refractometer (WYA - 2 S China) according to Brix reading.

Determination of $\mathrm{pH}$ : $\mathrm{pH}$ level of the berry fruits was measured using a pH-meter at $20^{\circ} \mathrm{C}$ (Tosun et al., 2008).

Determination of vitamin $C$ : Determination of vitamin $\mathrm{C}$ was performed by HPLC method as described by Koyuncu et al. (2010). The columns used were $250 \mathrm{~mm} \mathrm{x}$ $4.6 \mathrm{~mm}, \mathrm{dp}=5 \mu \mathrm{m}$ (Symmetry, Waters, Ireland), The mobile phases were water adjusted to $\mathrm{pH} 3.0$ with phosphoric acid. The UV detector (Varian pro Star, Australia) was set at $215 \mathrm{~nm}$. Quantitation was based on the peak area measurement. For HPLC (Varian-Prostar 500 , USA), $20 \mu \mathrm{L}$ of the sample were injected.

Determination of total anthocyanins: Anthocyanin quantitation was performed by the $\mathrm{pH}$ differential method of Giusti et al. (2001). Samples were diluted $1: 150$ in $\mathrm{pH}$ 1.0 and $\mathrm{pH} 4.5$ buffers, and then measured at 520 and 700 $\mathrm{nm}$ in UV - Visible spectrophotometer (A \& E Lab Co LTD, UK). It was based on a cyanidin 3 - glucoside molar extinction coefficient of $26,900 \Delta \mathrm{E} / \mathrm{mol}$ and a molecular weight of $449.2 \mathrm{~g} / \mathrm{mol}$. Resultant values were expressed in terms of mg of anthocyanins $100 \mathrm{~g}$ of fresh fruit.

Determination of total phenolics: Determination of Total Phenolics (TPC) was performed by Bond et al. (2003). As aliquot of $1.0 \mathrm{~mL}$ of diluted sample extract was vortexed with $10 \mathrm{~mL}$ DI water and $1.0 \mathrm{~mL}$ FolinCiocalteau reagent, and a $1.0 \mathrm{~mL}$ deionized water was used as control. After equilibration at room temperature for $8 \mathrm{~min}$, the solutions were mixed with $4 \mathrm{~mL}$ of $7.5 \%$ (w/v) $\mathrm{Na}_{2} \mathrm{CO}_{3}$. The samples and standards (Gallic acid dilute working standard solutions: $10-50 \mu \mathrm{gmL}^{-1}$ ) were equilibrated at room temperature for 60 minutes. The absorbance of the samples and standards were measured spectrophotometrically (UV/Vis spectrophotometer, A\&E Lab Co LTD, UK) at $765 \mathrm{~nm}$, with a $10 \mathrm{~mm}$ path length 
cell. TPC was calculated as mg of gallic acid equivalents per $100 \mathrm{~g}$ fresh weight of sample.

Determination of individual anthocyanins by HPLC: Determination of Anthocyanins by HPLC Analyses was performed by a Varian - Prostar - 500 series liquid chromatograph. Separation was achieved on a C18, 150 $\mathrm{mm}$ x $4.6 \mathrm{~mm}$ column. Solvents used were: (A) Aqueous Trifluoroacetic acid (TFA) $0.1 \%$, and (B) Methanol $100 \%$, establishing the following gradient: isocratic $6 \% \mathrm{~B}$ for $5 \mathrm{~min}, 30 \% \mathrm{~B}$ over $10 \mathrm{~min}$, isocratic $50 \% \mathrm{~B}$ for 15 min, $60 \% \mathrm{~B}$ over $5 \mathrm{~min}$, and $6 \% \mathrm{~B}$ over $10 \mathrm{~min}$, using a flow rate of $0.4 \mathrm{~mL} \mathrm{~min}^{-1}$, using $518 \mathrm{~nm}$ wavelength, and a mass spectrometer (MS, Varian-prostar-500, USA) connected to the HPLC system. The Mass Spectrometer (MS) was equipped with an Electro Spray Ionization (ESI) source and an ion trap mass analyzer. Spectra were recorded in positive ion mode 3500 volts. Quantification of anthocyanins content was carried out according to chromatographic peaks at $518 \mathrm{~nm}$ wavelength.

FRAP assay: The antioxidant capacity was determined following the procedure described by Benzie et al. (1996) with modifications. The FRAP reagent was freshly prepared by adding $10 \mathrm{mM} \mathrm{2,4,6-tripyridyl-s-}$ triazine (TPTZ) (dissolved in $40 \mathrm{mM}$ of $\mathrm{HCl}$ ), $20 \mathrm{mM}$ of $\mathrm{FeCl}_{3}$ in water and $300 \mathrm{mM}$ of acetate buffer $(\mathrm{pH}$ 3.6) in the ratio of $1: 1: 10$. The FRAP reagent was warmed to $37^{\circ} \mathrm{C}$ for 15 minutes. Then, $100 \mu \mathrm{L}$ of sample was added to $3.0 \mathrm{~mL}$ reagent blank. The absorbance was recorded at $593 \mathrm{~nm}$. The reaction was monitored for $4 \mathrm{~min}$. FRAP values of samples were compared to that of ascorbic acid and expressed as vitamin $\mathrm{C}$ equivalents per $100 \mathrm{~g}$ of fresh fruits.

\section{Statistical Analysis}

The data represents the mean of three replicates \pm standard deviation (SD). Data were subjected to the $t$ test. All calculations were performed with Microsoft Excel (Version 4, statistical functions, Microsoft Corp., Redmond, WA, USA).

\section{Results and discussion}

Quality parameters such as weight loss, vitamin C content, total polyphenols and total anthocyanins, as well as main individual anthocyanins were monitored at the initial sampling and after 8 days of storage at $0^{\circ} \mathrm{C}$. After 8 - 10 days most fruits became molded and damaged and the storage was discontinued.

\section{Weight Loss}

Fruit weight loss is associated with respiration and moisture evaporation through the skin. Table 1 shows weight loss during cold storage $\left(0^{\circ} \mathrm{C}\right.$ and $\left.90 \pm 5 \% \mathrm{RH}\right)$. All samples of blackberries demonstrated practically insignificant loss of weight during storage.

The data in Table 1 shows that during storage $\left(0^{\circ} \mathrm{C}\right.$ and $90 \pm 5 \% \mathrm{RH}$ ) raspberry fruits lost from 5.3 up to $16 \%$ weight depending on calcium treatment. Maximum lost was observed for untreated fruits (16\%) and minimum lost was observed for fruits treated with $2 \%$ calcium chloride $(5.3 \%)$. Similarly, untreated strawberry fruits lost maximum weight $(8.5 \%)$ and treated with $2 \%$ calcium chloride - only $4.1 \%$, that is more than two times less than untreated fruits. The lower weight loss in samples treated with calcium chloride dip may be due to increased water holding by formation of calcium pectate hydrogel and delay in dehydration process. (Lester et al., 1999)

\section{$T A$}

TA changed from $1.00 \pm 0.05$ to $0.90 \pm 0.05$ equally for all the samples of blackberries during storage period. The TA of untreated raspberries and strawberries decreased from $2.34 \pm 0.05$ to $1.71 \pm 0.02$ and from 0.81 \pm 0.03 to $0.70 \pm 0.03$ respectively in days of storage. Application of calcium chloride did not significantly influence this parameter (Table 2).

\section{Initial TSS}

TSS content of blackberry fruit was $12.5 \pm 0.5$ After 8 days of storage. TSS increased up to $12.90 \pm 0.07$ in the untreated sample of blackberries (Table 2). After 8 days storage TSS decreased to $11.60 \pm 0.66$ and $11.50 \pm 0.10$ in the treated samples with $1 \%$ and $2 \%$ calcium chloride respectively, probably because of respiration process. The initial TSS content was $11.00 \pm 0.08$ and $8.55 \pm 0.15$ for raspberry and strawberry fruits respectively. After 8 days storage TSS decreased to $10.22 \pm 0.06,9.60 \pm 0.05$ and $9.65 \pm 0.12$ in raspberry fruits treated with 0,1 and $2 \%$ calcium chloride respectively and to $7.00 \pm 0.17,6.57 \pm$ 0.08 and $6.35 \pm 0.04$ in strawberry fruits treated with 0,1 and $2 \%$ calcium chloride respectively (Table 2 ).

The decrease of TSS in $1 \%$ and $2 \%$ calcium chloride also might be due to the fact that more concentration of calcium chloride formed a thin layer on the surface of fruit which delayed degradation process of polysacharides. The increase in TSS in blackberry fruit is attributed to the dehydration process and to the enzymatic conversion of higher polysacharides such as starches and pectins into simple sugars (Hussain et al., 2008).

\section{pH Value}

Changes in $\mathrm{pH}$ values of fruits during storage period were not statistically significant (Table 2).

\section{Vitamin C Content}

Ascorbic acid is an important nutrient and is very sensitive to degradation due to its oxidation compared to other nutrients during food processing and storage (Veltman et al., 2000). There was no significant change in ascorbic acid content during 8 days of storage period in blackberry fruits untreated with calcium chloride (Table 2 ). This may be due very short period of storage ( 8 days) which is insufficient to the oxidation process of ascorbic acid in darkness. Whereas, samples treated with $1 \%$ and $2 \%$ calcium chloride showed increased ascorbic acid content by 15.7 and $37.5 \%$ respectively. The increasing of ascorbic acid content during storage may be due to the continuing process of biosynthesis of vitamin $\mathrm{C}$, which seems to be a physiological response of the fruit cells on some damages caused by calcium chloride treatment. 
Such increasing in ascorbic acid content in post harvested apples was reported by Poovaiah, (1986). Initial content of ascorbic acid in raspberry and strawberry was $23.87 \pm$ 0.35 and $45.17 \pm 0.24 \mathrm{mg}$ per $100 \mathrm{~g}$ of fruits. Eight days of storage resulted in oxidative degradation of ascorbic acid down to $12.98 \pm 0.12(54 \%)$ and $27.35 \pm 0.35(77 \%)$ mg per $100 \mathrm{~g}$ of untreated raspberry and strawberry fruits respectively. After storage, ascorbic acid content was significantly $(\mathrm{P} \leq 0.05)$ higher in samples of raspberry and strawberry fruits subjected to $2 \%$ calcium chloride dip. In the strawberry fruits this difference was even more: 27.35 $\pm 0.35 \mathrm{mg} / 100 \mathrm{~g}$ in the untreated fruits and $34.68 \pm 0.42$ $\mathrm{mg} / 100 \mathrm{~g}$ in the $2 \%$ calcium chloride treated fruits (Table 2).

These results showed that $\mathrm{CaCl}_{2}$ treatments had a significant effect on retaining ascorbic acid content in raspberry and strawberry fruits. This might be because higher concentrations of $\mathrm{CaCl}_{2}$ delayed the rapid oxidation of ascorbic acid in the samples.

\section{TPC and Antioxidant Potential}

Berry fruits are good source of polyphenolics (Hassimotto et al., 2008). Table 3 shows that treatment of blackberry, raspberry and strawberry fruits with calcium chloride had a positive effect on retaining polyphenols during storage period. Effect of calcium treatment was statistically significant between untreated and treated with
1 and $2 \%$ calcium chloride fruits $(\mathrm{P}<0.05)$. This might be because the addition of calcium chloride to berries strengthened the cell wall, enhanced the formation of egg box structure and minimized syneresis/leaching of water soluble compounds such as polyphenols. Also, calcium chloride treatment decreases polyphenol oxidase (PPO) activity (Tomas-Barberan et al., 1997) and by such way prevents polyphenols oxidation. TPC and antioxidant potential are well correlated in most cases (Balik et al. 2008). In our study reduction in polyphenols content of untreated sample of blackberries by $13.6 \%$ reflected in reduction of antioxidant potential by $25 \%$ (Table 3 ). In the samples treated with $1 \%$ and $2 \%$ calcium chloride reduction of polyphenols content by 12.4 and $7.5 \%$ caused reduction of antioxidant potential by 15.6 and $8.7 \%$ respectively. Calcium chloride treatment had positive effect on retaining antioxidant potential in both fruits samples of raspberries and strawberries. 66 and 74 $\%$ of antioxidant potential was retained in the untreated samples of raspberry and strawberry respectively. Whereas, in the treated samples maximum antioxidant potential was retained up to 78 and $89 \%$ in raspberry and strawberry fruits. Correlation coefficient between polyphenolics content and antioxidant activity was between 0.91 and 0.95 , which is not high probably because presence of ascorbic acid and its contribution to the antioxidant potential.

Table 1 Effect of calcium chloride treatment on weight loss of berries after storage (at $0 \pm 0.5^{\circ} \mathrm{C}, \mathrm{RH} 90 \pm 5 \%$ )

\begin{tabular}{c|cccc}
\hline \multirow{2}{*}{ Berry } & $\begin{array}{c}\text { Treatments \% } \\
\text { calcium chloride }\end{array}$ & Initial weight g & $\begin{array}{c}\text { Weight after storage } \\
\text { (8 days) g. }\end{array}$ & Weight loss \% \\
\hline \multirow{3}{*}{ Blackberry } & 0 & $34.79 \pm 0.10$ & $34.46 \pm 0.14$ & $0.93 \pm 0.01$ \\
& 1 & $44.01 \pm 0.21$ & $43.64 \pm 0.74^{\mathrm{b}}$ & $0.84 \pm 0.02^{\mathrm{b}}$ \\
& 2 & $43.06 \pm 0.45$ & $42.75 \pm 0.25^{\mathrm{b}}$ & $0.71 \pm 0.02^{\mathrm{b}}$ \\
Raspberry & 0 & $14.22 \pm 0.14$ & $11.92 \pm 0.01$ & $16.00 \pm 0.05$ \\
& 1 & $11.71 \pm 0.05$ & $10.64 \pm 0.07^{\mathrm{b}}$ & $9.10 \pm 0.02^{\mathrm{b}}$ \\
& 2 & $12.48 \pm 0.02$ & $11.81 \pm 0.03^{\mathrm{b}}$ & $5.30 \pm 0.02^{\mathrm{b}}$ \\
Strawberry & 0 & $18.90 \pm 0.10$ & $17.29 \pm 0.08$ & $8.50 \pm 0.02$ \\
& 1 & $21.01 \pm 0.12$ & $19.74 \pm 0.14^{\mathrm{b}}$ & $6.00 \pm 0.01^{\mathrm{b}}$ \\
\hline
\end{tabular}

The data represents the mean of three replicates $\pm \mathrm{SD}$; a - difference between test and control samples is not statistically significant. $b$ - difference between test and control samples is statistically significant

Table 2 Effect of calcium chloride treatment on quality parameters of berries after storage (at $0 \pm 0.5^{\circ} \mathrm{C}, \mathrm{RH} 90 \pm 5 \%$ )

\begin{tabular}{|c|c|c|c|c|c|c|}
\hline Berry & $\begin{array}{c}\text { Storage } \\
\text { period (days) }\end{array}$ & $\begin{array}{c}\text { Treatments \% } \\
\text { calcium chloride }\end{array}$ & TSS \% & $\mathrm{pH}$ & TA $\%$ & 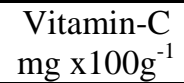 \\
\hline \multirow{4}{*}{ Blackberry } & 0 & fresh & $12.50 \pm 0.50$ & $3.70 \pm 0.02$ & $1.00 \pm 0.05$ & $31.20 \pm 0.15$ \\
\hline & 8 & 0 & $12.90 \pm 0.07^{\mathrm{b}}$ & $3.69 \pm 0.01$ & $0.92 \pm 0.02^{\mathrm{b}}$ & $31.10 \pm 0.69^{\mathrm{a}}$ \\
\hline & 8 & 1 & $11.60 \pm 0.66$ & $3.70 \pm 0.02$ & $0.93 \pm 0.05^{\mathrm{b}}$ & $36.10 \pm 0.66^{\mathrm{a}}$ \\
\hline & 8 & 2 & $11.50 \pm 0.10^{\mathrm{b}}$ & $3.70 \pm 0.04$ & $0.90 \pm 0.05^{\mathrm{b}}$ & $42.90 \pm 0.10^{\mathrm{b}}$ \\
\hline \multirow{4}{*}{ Raspberry } & 0 & fresh & $11.00 \pm 0.08$ & $2.45 \pm 0.01$ & $2.34 \pm 0.05$ & $23.87 \pm 0.35$ \\
\hline & 8 & 0 & $10.22 \pm 0.06^{\mathrm{b}}$ & $2.45 \pm 0.00$ & $1.71 \pm 0.08^{\mathrm{b}}$ & $12.98 \pm 0.12^{b}$ \\
\hline & 8 & 1 & $9.60 \pm 0.05^{\mathrm{b}}$ & $2.45 \pm 0.06$ & $1.76 \pm 0.02^{b}$ & $14.96 \pm 0.25^{\mathrm{b}}$ \\
\hline & 8 & 2 & $9.65 \pm 0.12^{\mathrm{b}}$ & $2.44 \pm 0.02$ & $1.77 \pm 0.02^{b}$ & $17.05 \pm 0.31^{b}$ \\
\hline \multirow{4}{*}{ Strawberry } & 0 & fresh & $8.55 \pm 0.15$ & $3.50 \pm 0.02$ & $0.81 \pm 0.02$ & $45.17 \pm 0.24$ \\
\hline & 8 & 0 & $7.00 \pm 0.17^{\mathrm{b}}$ & $3.51 \pm 0.00$ & $0.72 \pm 0.03^{b}$ & $27.35 \pm 0.35^{\mathrm{b}}$ \\
\hline & 8 & 1 & $6.57 \pm 0.08^{\mathrm{b}}$ & $3.50 \pm 0.02$ & $0.67 \pm 0.02^{b}$ & $29.85 \pm 0.17^{b}$ \\
\hline & 8 & 2 & $6.35 \pm 0.04^{\mathrm{b}}$ & $3.50 \pm 0.00$ & $0.67 \pm 0.04^{\mathrm{b}}$ & $34.68 \pm 0.42^{b}$ \\
\hline
\end{tabular}

The data represents the mean of three replicates $\pm \mathrm{SD}$; $\mathrm{a}$ - difference between test and control samples is not statistically significant. $\mathrm{b}$ - difference between test and control samples is statistically significant 
Table 3 Effect of calcium chloride treatments on TPC, monomeric anthocyanin content and FRAP of berries after storage (at $0 \pm 0.5^{\circ} \mathrm{C}, \mathrm{RH} 90 \pm 5 \%$ )

\begin{tabular}{|c|c|c|c|c|c|}
\hline Berry & $\begin{array}{l}\text { Storage period } \\
\text { (days) }\end{array}$ & $\begin{array}{c}\text { Treatments \% } \\
\text { Calcium chloride }\end{array}$ & $\begin{array}{l}\text { TPC mg } \\
100 g^{-1}\end{array}$ & $\begin{array}{c}\text { Monomeric } \\
\text { anthocyanins mg100g } \\
\end{array}$ & $\begin{array}{l}\text { FRAP mg equivalents } \\
\text { vitamin-C } \times 100 \mathrm{~g}^{-1}\end{array}$ \\
\hline \multirow{4}{*}{ Blackberry } & 0 & fresh & $177.12 \pm 0.85$ & $128.58 \pm 2.53$ & $335.23 \pm 3.56$ \\
\hline & 8 & 0 & $152.94 \pm 0.34^{b}$ & $122.60 \pm 1.45^{b}$ & $251.40 \pm 2.15^{b}$ \\
\hline & 8 & 1 & $155.14 \pm 0.44^{b}$ & $124.20 \pm 2.78^{\mathrm{a}}$ & $283.00 \pm 4.23^{b}$ \\
\hline & 8 & 2 & $163.93 \pm 1.03^{b}$ & $125.36 \pm 1.65^{\mathrm{a}}$ & $306.00 \pm 3.20^{b}$ \\
\hline \multirow{4}{*}{ Raspberry } & 0 & fresh & $116.01 \pm 1.25$ & $33.34 \pm 0.52$ & $220.00 \pm 3.56$ \\
\hline & 8 & 0 & $105.58 \pm 2.41^{b}$ & $23.35 \pm 0.42^{b}$ & $146.63 \pm 4.23^{b}$ \\
\hline & 8 & 1 & $113.38 \pm 2.20^{\mathrm{a}}$ & $29.26 \pm 0.15^{b}$ & $173.72 \pm 3.65^{b}$ \\
\hline & 8 & 2 & $109.98 \pm 1.65^{b}$ & $27.88 \pm 0.71^{b}$ & $167.70 \pm 4.82^{b}$ \\
\hline \multirow{4}{*}{ Strawberry } & 0 & fresh & $152.94 \pm 2.45$ & $63.87 \pm 0.51$ & $413.10 \pm 3.52$ \\
\hline & 8 & 0 & $130.60 \pm 2.75^{b}$ & $49.29 \pm 1.42^{b}$ & $357.19 \pm 2.75^{b}$ \\
\hline & 8 & 1 & $136.13 \pm 3.85^{b}$ & $52.17 \pm 0.98^{b}$ & $368.75 \pm 4.32^{b}$ \\
\hline & 8 & 2 & $145.37 \pm 3.15^{b}$ & $54.34 \pm 1.05^{b}$ & $306.08 \pm 4.95^{b}$ \\
\hline
\end{tabular}

The data represents the mean of three replicates $\pm \mathrm{SD}$; $\mathrm{a}$ - difference between test and control samples is not statistically significant. $\mathrm{b}$ - difference between test and control samples is statistically significant

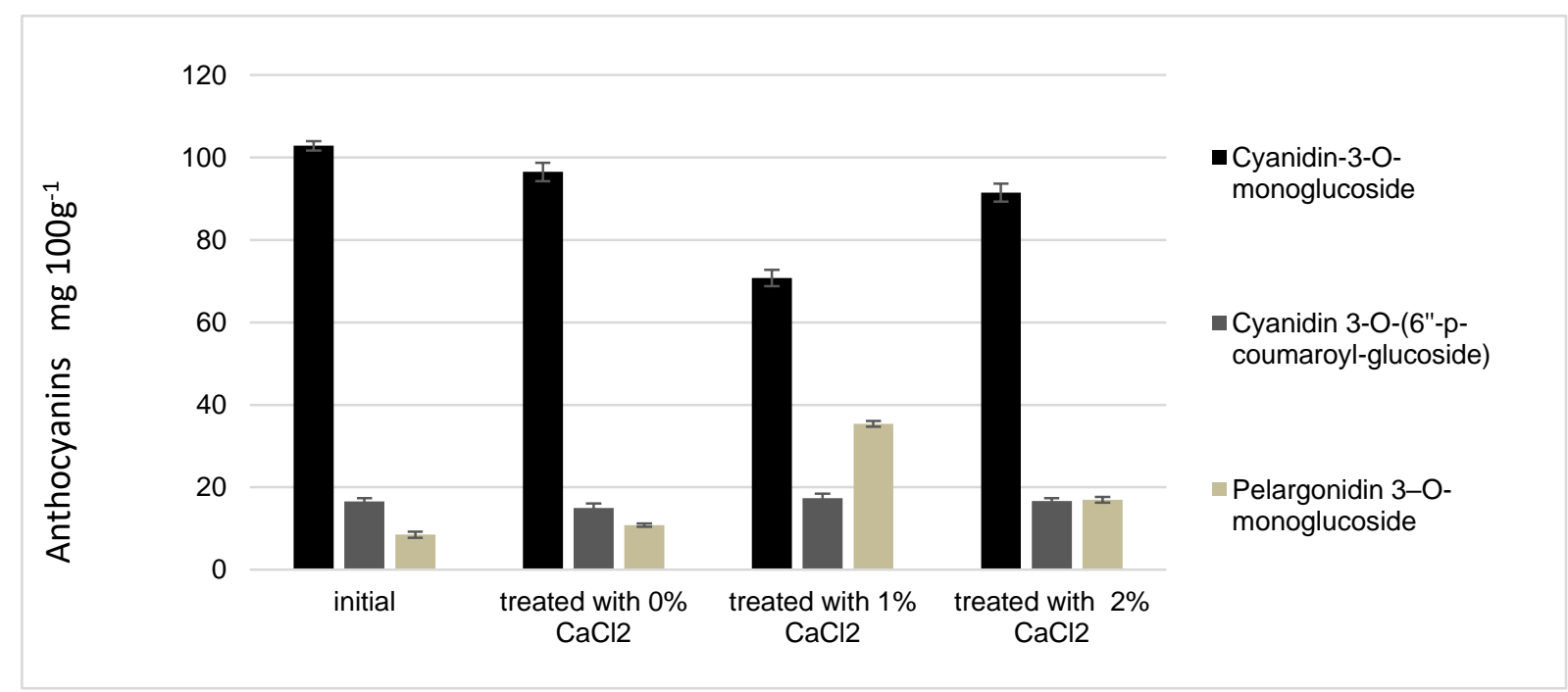

Figure 1 Changes in content of individual anthocyanins during storage period in blackberry fruit

\section{Anthocyanin Content}

The most important polyphenols of strawberries and raspberries are anthocyanins and the main anthocyanin of strawberries is pelargonidin 3-O-monoglucoside and the main anthocyanin of raspberries and blackberries are cyanidin-3-O-monoglucoside. The data in Table 3 shows that total anthocyanins in untreated sample of raspberry were reduced by $30 \%$, whereas in the $1 \%$ and $2 \%$ calcium treated samples total anthocyanins reduced by 12 and $15 \%$, respectively. For the strawberry fruits reduction of anthocyanins in the untreated sample was $23 \%$, whereas in the 1 and $2 \%$ calcium treated strawberry samples total anthocyanins reduction was 19 and $15.5 \%$ respectively.

Figure 1 shows changes in anthocyanin contents after 8 days storage period in blackberry fruit. As shown, total anthocyanins in untreated sample reduced by $4.5 \%$, whereas in the 1 and $2 \%$ calcium treated samples total anthocyanins reduced only by 3.3 and $2.5 \%$ respectively. The difference was statistically significant between untreated and treated with $2 \%$ calcium chloride fruits $(\mathrm{P}<0.05)$.

Our research showed that content of cyanidine $-3-\mathrm{O}$ -monoglucoside decreased by $6.33,32.06$ and $11.35 \mathrm{mg}$ per $100 \mathrm{~g}$ of fruit in case of storage of untreated, treated with 1 and $2 \%$ calcium chloride respectively. Whereas, content of pelargonidin $3-\mathrm{O}$ - monoglucoside increased respectively by $2.29,26.87$ and $8.45 \mathrm{mg}$ per $100 \mathrm{~g}$ fruits (Figure 1). This may be because pectin binds anthocyanins, some more tightly than others, more tightly at different $\mathrm{pH}$ values (Lin et al., 2016). The addition of calcium changes these bindings and results in changes of individual anthocyanins content.

Change of content of Cyanidin $3-\mathrm{O}-(6-\mathrm{p}-$ coumaroyl - glucoside) was not statistically significant.

Unfortunately, authors were unable to identify changes in individual anthocyanins of strawberry and raspberry fruits because of unavailability respective samples of the main individual anthocyanins of these fruits. 


\section{Conclusion}

- The application of calcium did not significantly effect on the whole of characteristics of qualities, such as TA, $\mathrm{pH}$ and TSS. Though, treatment with $2 \%$ calcium chloride had a slight influence on the taste of fruits. In order to retain quality and good taste of the fruits during cold storage, it is recommended to treat berry fruits with $1 \%$ calcium chloride.

- The berry fruits treated with calcium (1 and 2\%) by immersion increased their ascorbic acid content.

- $\quad$ TPC and antioxidant potential in stored fruit was higher if treated with calcium chloride. Calcium chloride treatment also had positive effect on the retaining process of monomeric anthocyanins during storage. Calcium chloride dip is a practical way to extend shelf life and nutritional quality of blackberries, raspberries and strawberries during chilled storage.

- The application of calcium changed content of individual anthocyanins of blackberries because their binding to pectin compounds.

\section{Acknowledgements}

Authors declare no conflict of interest. The research was carried out in the framework of the research task financed by Shota Rustaveli National Science Foundation (SRNSF), no. AR/94/10-160/13.

\section{References}

Aghdam MS, Pouraghdam MBH, Paliyath G, Farmani B. 2012. The language of calcium in postharvest life of fruits, vegetables and flowers. Scientia Horticulturae, 144: 102-115.

Astuti NK, Maghfoer MD, Soelistyono R. 2013. Calcium Chloride Applications to Improve Fruit Quality on Bruised and Diseased of Pineapple (Ananas comosos (L) Merr). Applied Chemistry, 5: 30-34.

Balik J, Kyseláková M, Vrchotová N, Tŕiska L, Kumśta M, Veverka J, Hic P, Totuśek J, Lefberová D. 2008. Relations between Polyphenols Content and Antioxidant Activity in Vine Grapes and Leaves. Czech Journal of Food Sciences, 26: S25 - S32.

Beattie J, Crozier A, Duthie G. 2005. Potential health benefits of berries.Current Nutrition and Food Science, 1: 71 - 86.

Benzie IFF, Strain JJ. 1996. The ferric reducing ability of plasma (FRAP) as a measure of "antioxidant power": the FRAP assay. Analytical Biochemistry, 239: 70 - 76.

Bond TJ, Lewis JR, Davis A, Davis AP. 2003. Analysis and Purification of Catechins and Their Transformation Products. In C. Santos-Bulga, G. Williamson (Eds.), Methods of polyphenols analysis (pp. 229 - 265) The Royal Society of Chemistry, UK.

Burdulis D, Šarkinas A, Jasutienė I, Stackevičienė E, Nikolajevas L, Janulis V. 2009. Comparative study of anthocyanin composition antimicrobial and antioxidant activity in bilberry (Vaccinium Myrtillus L.) and Bluberry (vaccinium Corymbosum L.) fruits. Acta Poloniae Pharmaceutica, 66(4), 399-408.

De Souza VR, Pereira PA, Da Silva TL, De Oliveira Lima LC, Pio R, Quiroz F. 2014. Determination of the bioactive compounds, antioxidant activity and chemical composition of Brazilian blackberry, red raspberry, strawberry, blueberry and sweet cherry fruits. Food Chemistry, 156, 362-368.

Diaconeasa Z, Ranga F, Rugină D, Leopold L, Pop O, Vodnar D, Cuibus L, Socaciu C. 2015. Phenolic Content and Their Antioxidant Activity in Various Berries Cultivated in Romania. Journal of Food Science and Technology, 72(1) 99-103.
Ferguson IB. 1984. Calcium in plant senescence and fruit ripening. Plant Cell Environmental, 7:477 - 489.

Fortalezas S, Tavares L, Pimpao R, Tyagi M, Pontes V, Alves PM, McDougall G, Stewart D, Ferreira RB, Santos CN. 2010. Antioxidant properties and neuroprotective capacity of strawberry tree fruit (Arbutus unedo). Nutritional Science, 2:214-229.

Garcia JM, Herrera S, Morilla A. 1996. Effects of postharvest dips in calcium chloride on strawberry. Journal of Agricultural and Food Chemistry, 44: $30-33$.

Giusti MM, Wrolstad RE. 2001. Current Protocols in Food Analytical Chemistry. In R.E. Wrolstad (Ed.), Unit F1.2.1 - 13. Anthocyanins. Characterization and Measurement with UV Visible Spectroscopy, John Wiley \& Sons, New York. USA.

Halvorsen BL, Holte K, Myhrstad MC, Barikmo I, Hvattum E, Remberg SF, Wold A.B, Haffner K, Baugerod H, Andersen LF. 2002. A systematic screening of total antioxidants in dietary plants. Journal of Nutrition, 132:461-471.

Hassimotto NMA, Mota RV, Cordenunsi BR, Lajolo FM. 2008. Physico-chemical characterization and bioactive compounds of blackberry fruits (Rubus sp.) grown in Brazil. Ciencia e tecnologia de Alimentos, 28(3): 702 - 708.

Hussain PR, Dar MA, Meena RS, Mir MA, Shafi F, Wani AM. 2008. Changes in quality of apple (Malus domestica) cultivars due to gamma irradiation and storage conditions. Journal of Food Science and Technlogy, 45:444 - 449.

Ichiyanagi T, Hatano Y, Matsuo S, Konishi T. 2004. Simultaneous comparison of relative reactivities of twelve major anthocyanins in bilberry towards reactive nitrogen species. Chemical and Pharmaceutical Bulletin, 52: 1312- 1315.

Karlund A, Moor U, Sandall M, Karjalainen RO. 2014. The Impact of Harvesting, Storage and Processing Factors on HealthPromoting Phytochemicals in Berries and Fruits. Processes, 2:596 - 624 .

Koyuncu MA, Dilmaǵünal T. 2010. Determination of Vitamin $-\mathrm{C}$ and Organic Acid Changes in Strawberry by HPLC During Cold Storage. Notulae Botanicae Horti Agrobotanici, 38(3): 95 98.

Lester GE, Grusak MA. 1999. Postharvest application of calcium and magnesium to honeydew and netted muskmelons: Effects on tissue ion concentrations, quality and senescence. Journal of The American Society for Horticultural Science, 124: 545-552.

Lin Z, Fischer J, Wicker L. 2016. Intermolecular binding of blueberry pectin-rich fractions and anthocyanin. Food Chemistry, 194: 986 - 993.

Lurie S. 2009. Stress physiology and latent damage. In W.J. Florkowski, R.L.Shewfelt, B. Brueckner, S.E. Prussia (Eds.), Postharvest Handling: A Systems Approach, pp. 443-459 Academic Press.

Machado FLC, Alves RE, Figueiredo RW. 2008. Application of 1methylcyclopropene, calcium chloride and calcium amino acid chelate on fresh-cut cantaloupe muskmelon. Pesquisa Agropecuaria Brasileira, 43:569-574.

Morris JR, Sistrunk WA, Sims CA, Main GL, Wehunt EJ. 1985. Effects of cultivar, postharvest storage, preprocessing dip treatments and style of pack on the processing quality of strawberries. Journal of the American Society for Horticultural Science, 110: 172 - 177.

Namiesnik J, Vearasilp K, Nemirovski A, Leontowicz H, Leontowicz M, Pasko P, Martinez-Ayala AL, González-Aguilar GA, Suhaj M, Gorinstein S. 2014. In vitro studies on the relationship between the antioxidant activities of some berry extracts and their binding properties to serum albumin. Applied Biochemistry and Biotechnology,182: 2849-2865.

Panico AM, Garufi F, Nitto S, Di Mauro R, Longhitano RC, Magrì G, A. Catalfo A, ME. Serrentino ME, De Guidi G. 2009. Antioxidant activity and phenolic content of strawberry genotypes from Fragaria $\mathrm{x}$ ananassa, Pharmaceutical Biology, 47(3):203-208. 
Pantelidis GE, Vasilakakis M, Manganaris GA, Diamantidis G. 2007. Antioxidant capacity, phenol, anthocyanin and ascorbic acid contents in raspberries, blackberries, red currants, gooseberries and Cornelian cherries. Food Chemistry, 102: 777783.

Poovaiah BW. 1986. Role of calcium in prolonging storage life of fruits and vegetables. Food Technology, 40:86 - 89.

Potter RM, Dougherty MP, Halteman WA, Camire ME. 2007. Characteristics of wild Blueberry-Soy Beverages, Food Science and Technology, 40: 807-814.

Prior RL. 2003. Fruits and vegetable in the prevention of cellular oxidative damage, The American Journal of Clinical Nutrition, 570s-578s.

Prior RL, Wu X. 2012. Analysis methods of Anthocyanins. In Z. $\mathrm{Xu}$, L.R. Howard (Eds.), Analysis of Antioxidant-Rich Phytochemicals (pp. 149 - 180) Wiley-Blackwell, USA.

Puupponen-Pimiä R, Nohynek L, Hartmann-Schmidlin S, Kähkönen M, Heinonen M, Maatta-Riihinen K, Oksman-Caldentey KM. 2005. Berry phenolics selectively inhibit the growth of intestinal pathogens. Journal of Applied Microbiology, 98:991-1000.

Rodriguez-Saona LE, Wrolstad RE. 2001. Current Protocols in Food Analytical Chemistry. In R.E. Wrolstad (Ed.), Unit F1.1.1 - 11, Anthocyanins. Extraction, Isolation and Purification of Anthocyanins. John Wiley \& Sons, New York, USA.

Skrovankova S, Sumczynski D, Mlcek J, Jurikova T, Sochor J. 2015. Bioactive Compounds and Antioxidant Activity in Different Types of Berries. International Journal of Molecular Sciences, 16: 24673-24706.
Slatnar A, Jakopic J, Stampar F, Veberic R, Jamnik P. 2012. The effect of bioactive compounds on in vitro and in vivo antioxidant activity of different berry juices. PLOS ONE, 7: 10.

Tomas-Barberan FA, Gil MI, Castańer M, Artes F, Saltveit ME. 1997. Effect of Selected Browning Inhibitors on Phenolic Metabolism in Stem Tissue of Harvested Lettuce. Journal of Agricultural and Food Chemistry, 45:583-589.

Tosun I, Ustun NS, Tekguler B. 2008. Physical and chemical changes during ripening of blackberry fruits. Scientia Agricola, 65: 87-90.

Veltman RH, Kho RMA, Van-Schaik CR, Sanders MG, Oosterhaven J. 2000. Ascorbic acid and tissue browning in pears under controlled atmosphere conditions. Postharvest Biology and Technology, 19: 129-137.

Vicente AR, Manganaris GA, Sozzi GO, Crisosto CH. 2009. Nutritional quality of fruits and vegetables. In W.J. Florkowski,R.L.Shewfelt, B. Brueckner, S.E. Prussia (Eds.), Postharvest Handling: A Systems Approach (pp. 57 - 106). Academic Press, USA.

Wada L, Ou B. 2002. Antioxidant Activity and Phenolic Content of Oregon Caneberries. Journal of Agricultural and Food Chemistry, 50: 3495 - 3500 .

Wills RBH. 1998. Enhancement of senescence in non-climacteric fruit and vegetables by low ethylene levels. Acta Horticulturae, 464: 159 - 162.

Zheng W, Wang SY. 2003. Oxygen radical absorbing capacity of flavonoids and phenolic acids in blueberries, cranberries, chokeberries and lingonberries. Journal of Agricultral and Food Chemistry, 51:502-509. 